\title{
WestVirginiaUniversity
}

THE RESEARCH REPOSITORY @ WVU

West Virginia Agricultural and Forestry Experiment

Davis College of Agriculture, Natural Resources

Station Bulletins

And Design

$1-1-1966$

\section{Marketing West Virginia strawberries in out-of-state markets}

Robert L. Jack

Follow this and additional works at: https://researchrepository.wvu.edu/ wv_agricultural_and_forestry_experiment_station_bulletins

\section{Digital Commons Citation}

Jack, Robert L., "Marketing West Virginia strawberries in out-of-state markets" (1966). West Virginia Agricultural and Forestry Experiment Station Bulletins. 528.

https://researchrepository.wvu.edu/wv_agricultural_and_forestry_experiment_station_bulletins/484 @ WVU. It has been accepted for inclusion in West Virginia Agricultural and Forestry Experiment Station Bulletins by an authorized administrator of The Research Repository@WVU. For more information, please contact ian.harmon@mail.wvu.edu. 
West Virginia University Libraries

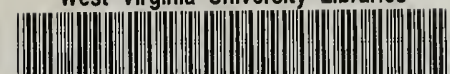

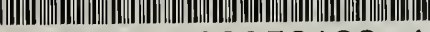

308021009521334 
Digitized by the Internet Archive in 2010 with funding from

Lyrasis Members and Sloan Foundation 


\section{THE AUTHOR}

Robert L. Jack is assistant Agricultural Economist in the West Virginia University Agricultural Experiment Station.

\section{ACKNOWLEDGMENT}

The author wishes to acknowledge Dr. William H. Conkle, Area Director for the Appalachian Center, who prepared the schedule and supervised the collection of data for this study.

West Virginia University Agricultural Experiment Station College of Agriculture and Forestry

A. H. Vanlandingham, Drrector 


\section{CONTENTS}

INTRODUCTION - 3

PURPOSE AND SCOPE - 3

ProcedURE -

Interest in Handiang West Virginia Strawberries _-_ 4

Primary Source of SUPPly _ ___ 9

DAILY VOLUME _._- 16

Size AND Quality DesiRed

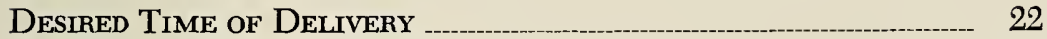

SHIPPINg UNDER ReFrigeration _.__ 24

Type of Package Preferked _-_ 24

SUMmaRY StatementS _-___ 26

ConCluSIONS _-__- 26 



\section{Marketing West Virginia Strawberries In Out-of-State Markets}

ROBERT L. JACK

\section{INTRODUCTION}

A LHOUGH THE BEAUTIFUL MOUNTAINS of central and southA ern West Virginia are rich in natural resources and have an esthetic value for all, they also produce difficult problems for agriculture. In these mountainous areas one finds many small, isolated, and widely separated parcels of cultivable land unsuited for efficient use of modern farm machinery. This inefficiency associated with small parcels makes it difficult for farmers in these areas to be competitve in the production of most field crops. Consequently, in central and southern West Virginia farm income is low relative to other areas of the state. Agricultural resources are not fully or efficiently employed and capital investment per farm is small.

It has been suggested that these problems of low farm income, surplus labor and underemployed agricultural resources can be partly eliminated by producing intensive crops that require large amounts of labor, small amounts of machinery, and return a relatively high net revenue per acre. Strawberries, snap beans, and field-grown tomatoes have been mentioned as possible crops which could fulfill these requirements.

\section{PURPOSE AND SCOPE}

The suggestion of intensive crops (strawberries, snap beans, fieldgrown tomatoes) as a partial solution for agricultural problems in West Virginia assumes two things. First, that there is a market for such crops. Second, that the attitude of West Virginia farmers is favorable toward growing these crops for commercial markets.

The purpose of this study is to investigate the soundness of the first assumption that a market is available for strawberries, snap beans, and tomatoes produced in West Virginia. More precisely the study attempted to:

1. Determine the locations in which wholesale markets are available for strawberries, snap beans, and field-grown tomatoes produced in West Virginia. 
2. Determine the competitive position of West Virginia strawberries, snap beans, and field-grown tomatoes in these markets by ascertaining primary and secondary sources of supply for each market area during the time period when West Virginia products would be marketed.

3. Determine the product quality, container, and shipping requirements of each market and of various types of buyers within each market.

Completion of the above objectives should indicate how strawberries, snap beans, and field-grown tomatoes must be graded, packaged, and shipped in order to satisfy wholesale buyers in markets where West Virginia can be most competitive.

Although this research project investigated markets for West Virginia strawberries, snap beans, and field-grown tomatoes, the analysis herein will be confined to strawberries.

\section{PROCEDURE}

Data for this study were collected by personal interviews with 109 wholesalers, commission merchants, and corporate food chains that buy strawberries, snap beans, and field-grown tomatoes. These firms were located in 11 cities situated in 10 states surrounding but not necessarily contiguous to West Virginia.

For purpose of analysis, the 11 cities were divided into three markets. The northern market is composed of buyers located in Pittsburgh, Cleveland, and Buffalo. The eastern market is composed of buyers located in Baltimore, Washington, Richmond, Raleigh, and Columbia. The southwestern market includes buyers located in Cincinnati, Louisville, and Nashville. These three different markets will be referred to throughout this report.

The three types of buying firms referred to in the analysis are commission merchants, food chains, and other wholesalers. The first two types of buyers are self explanatory. The other wholesaler category includes distributors, receivers, receiver-jobbers and others.

\section{INTEREST IN HANDLING WEST VIRGINIA STRAWBERRIES}

The 109 respondents interviewed were asked, "If we were to have 50,000 to 100,000 crates of strawberries in West Virginia during the May 15-June 30 period, would you be interested in handling some of them?" Responses to this question varied between markets and firms within markets (Figure 1).

Buying firms in the northern market were the most interested in handling West Virginia strawberries. In this market 78 per cent of the 

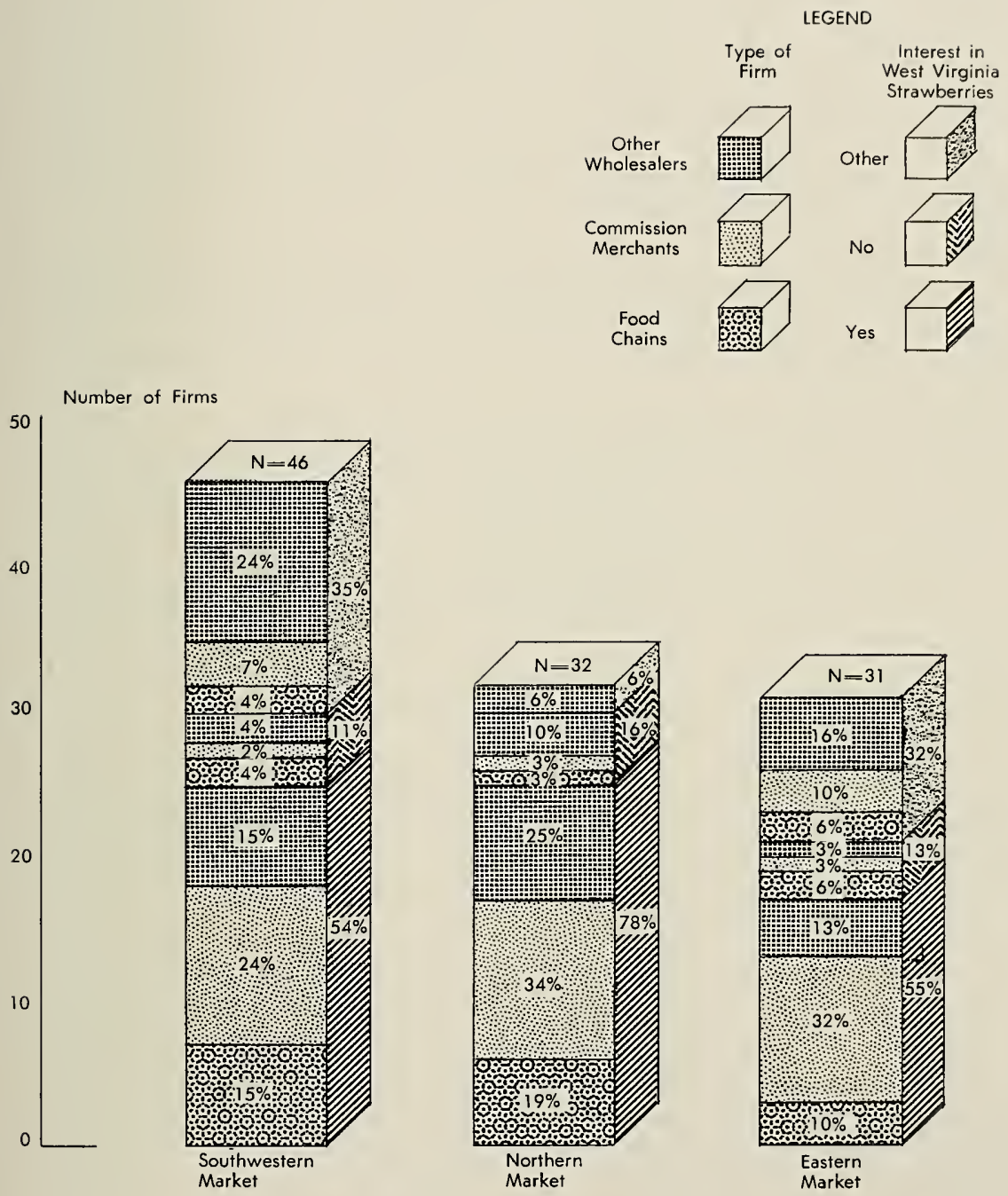

Figure 1. Interest in handling West Virginia strawberries distributed by three market areas and three types of firms. 
buyers gave a definite "yes" answer when asked if they would be interested in handling West Virginia strawberries. In the southwestern and eastern markets 54 and 55 per cent respectively gave definite "yes" answers. Only 22 per cent of the respondents in the northern market answered "no" or gave other answers compared to 46 per cent in the southwestern market and 45 per cent in the eastern market. About the same percentage of buyers in all three markets answered with a definite "no" when asked if they would be interested in handling West Virginia strawberries.

In all three markets, commission merchants accounted for the largest proportion of buyers definitely interested in West Virginia strawberries. Other wholesalers accounted for the largest share of "non-yes" answers in all three markets.

Based on data in Figure 1, West Virginia producers would find it easier to enter the northern market with their strawberries than to enter the southwestern or eastern markets. Entrance to all three markets should be easiest through commission merchants.

The remainder of the analysis in this report is concerned only with the 67 buyers definitely interested (answered yes) in handling West Virginia strawberries.

\section{FIRST CHOICE METHOD OF SELLING}

Suggested methods of selling varied with the type of buyer interviewed. More than 50 per cent of the buyers in all three markets preferred consignment selling for producers. Selling by the direct purchase method was the second most popular choice of selling recommended by buyers in all three markets (Figure 2).

As would be expected, most commission merchants suggested that West Virginia growers should sell their strawberries by consignment. Food chains were divided between direct purchase and buying agencies as methods of selling recommended to be used by West Virginia producers. None of the chains recommended the use of consignment selling. Other wholesalers were split between consignment and direct purchase as their recommended first choice method of selling West Virginia strawberries.

\section{SECOND CHOICE METHOD OF SELLING}

All three types of buyers tended to be firmly committed to the method of selling which they gave as their first choice for marketing West Virginia strawberries in Figure 2. About 50 per cent of the buyers in all three markets did not recommend a second method for selling West Virginia strawberries (Figure 3). Where a second method of selling was 
Number of Firms

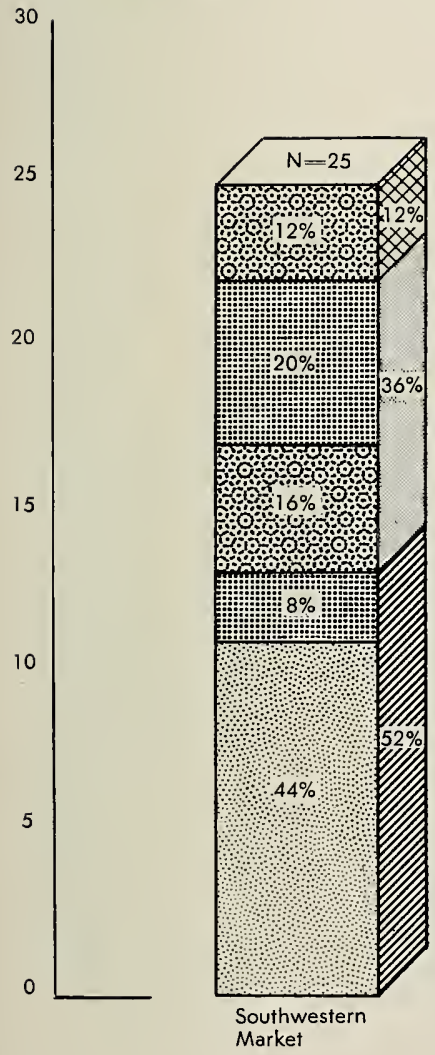

LEGEND

Type of
Firm

Method of

Selling

(1st Choice)
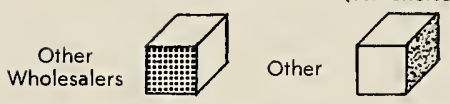

Commission

Merchants

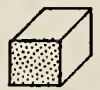

Other

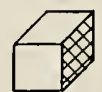

Agency

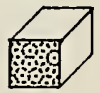

Direct

Purchase

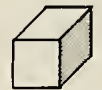

Consignment
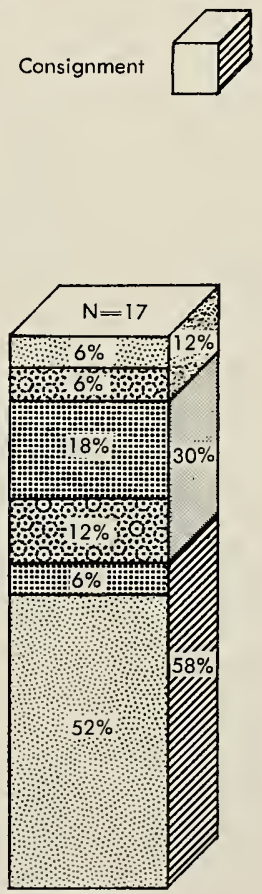

Eastern

Market

Figure 2. Responses to question, "What method or methods of selling strawberries should we use (1 st choice)?" distributed by three market areas and three types of firms. 
Number of Firms

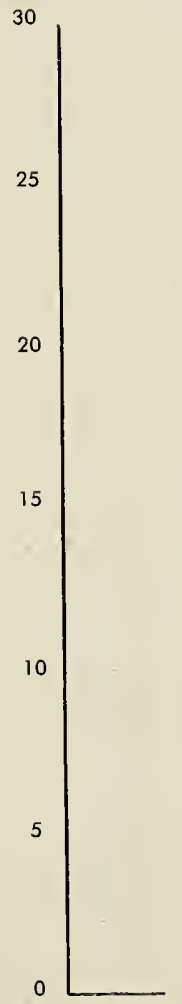

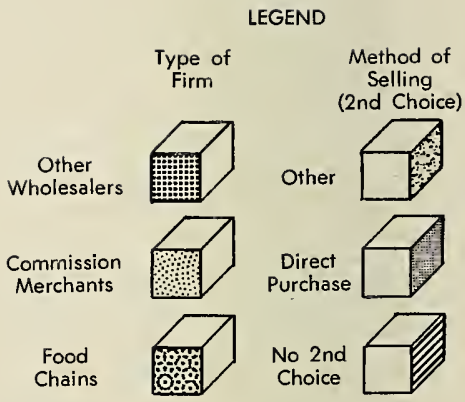
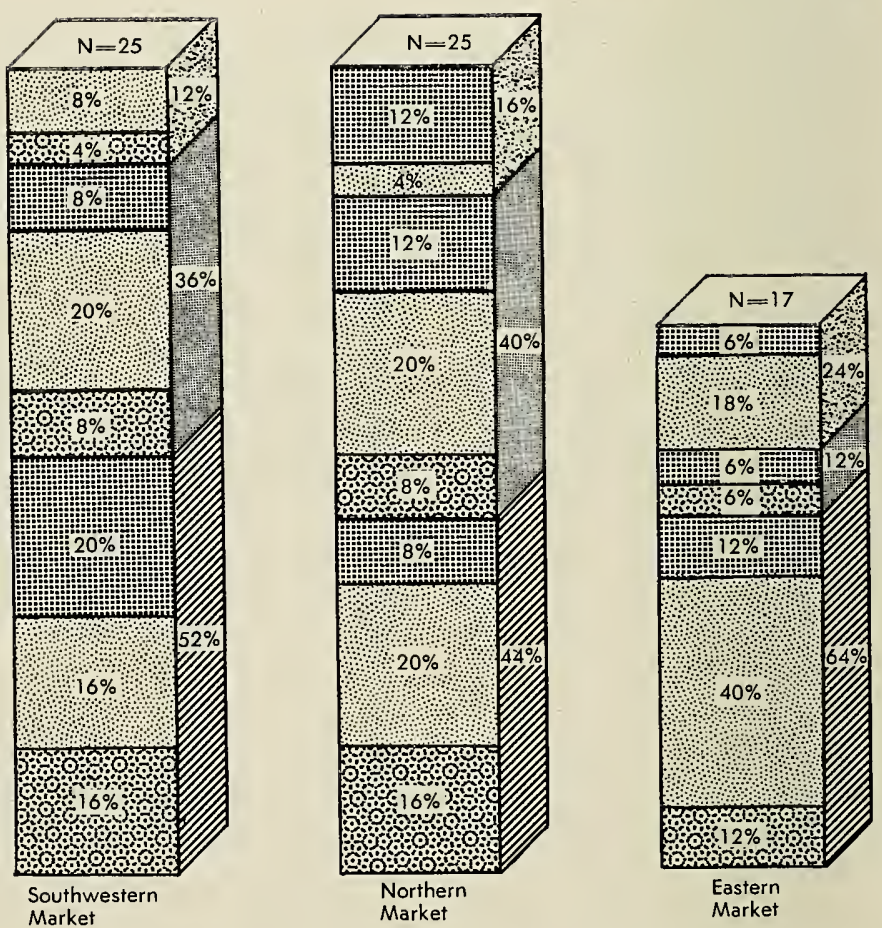

Figure 3. Responses to question, "What method or methods of selling strawberries should we use (2nd choice)?" distributed by three market areas and three types of firms. 
recommended, direct purchase was mentioned most often in the northern and southwestern markets.

The data in Figures 2 and 3 suggest that food chains prefer the direct purchase method of selling, commission merchants strongly prefer consignment or direct purchase selling, and other wholesalers favor consignment and/or direct purchase methods of selling for West Virginia strawberries.

\section{PRIMARY SOURCE OF SUPPLY}

The perishable nature of strawberries makes it necessary to hold the time interval between harvest and consumption to a minimum. Where markets are located great distances from the point of production, producers attempt to maintain high-quality strawberries by field cooling, by shipping under refrigeration, and by using rapid transportation to carry the strawberries to market in a short period of time. Although these additional marketing services enable producers to maintain high-quality strawberries that demand higher prices, the services also increase the cost of marketing, especially if long shipping distances are involved. Since producers located near the market should be able to maintain a highquality strawberry with a smaller quantity of these additional services, they should have a competitive advantage over growers located long distances from the markets.

Each buyer interviewed for this study was asked which region was his primary source of supply during different time periods of the strawberry season. The six supply regions used in the analysis are shown in Figure 4.

The primary source of strawberry supply from May 15-31 varied from one market to another (Figure 5). During this marketing period the South Atlantic, Western and South Central regions were the primary source of strawberry supply for 52 per cent or more of the buyers in all three markets. The South Central growers were major suppliers for the southwestern market, Western growers were major suppliers for the northern market, and South Atlantic growers were the major suppliers for the eastern market during the May 15-31 time period.

As the season progresses from the May 15-31 to June 1-15 time period, the primary supply regions for each market change. East North Central and Western Regions become the primary source of supply for 48 per cent of the buyers in the southwestern market (Figure 6). The Western and North Atlantic regions are now the major suppliers for 68 per cent of buyers in the northern market. In the eastern market, the South Atlantic region still is the primary supplier for 35 per cent of the buyers, and the North Atlantic region is the major supplier for 41 per cent of the buyers. 


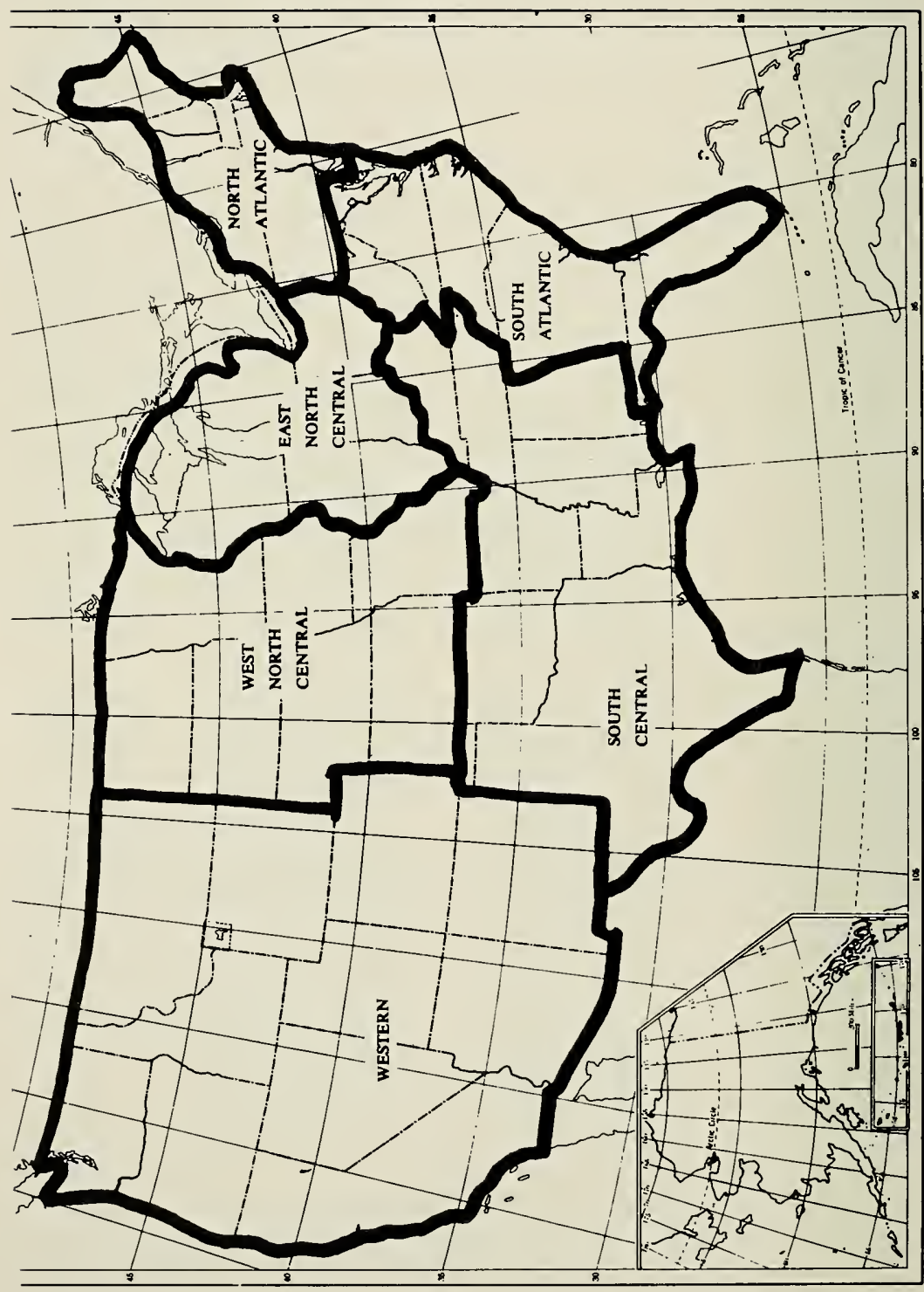

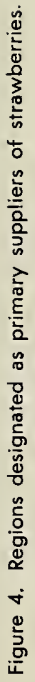


LEGEND
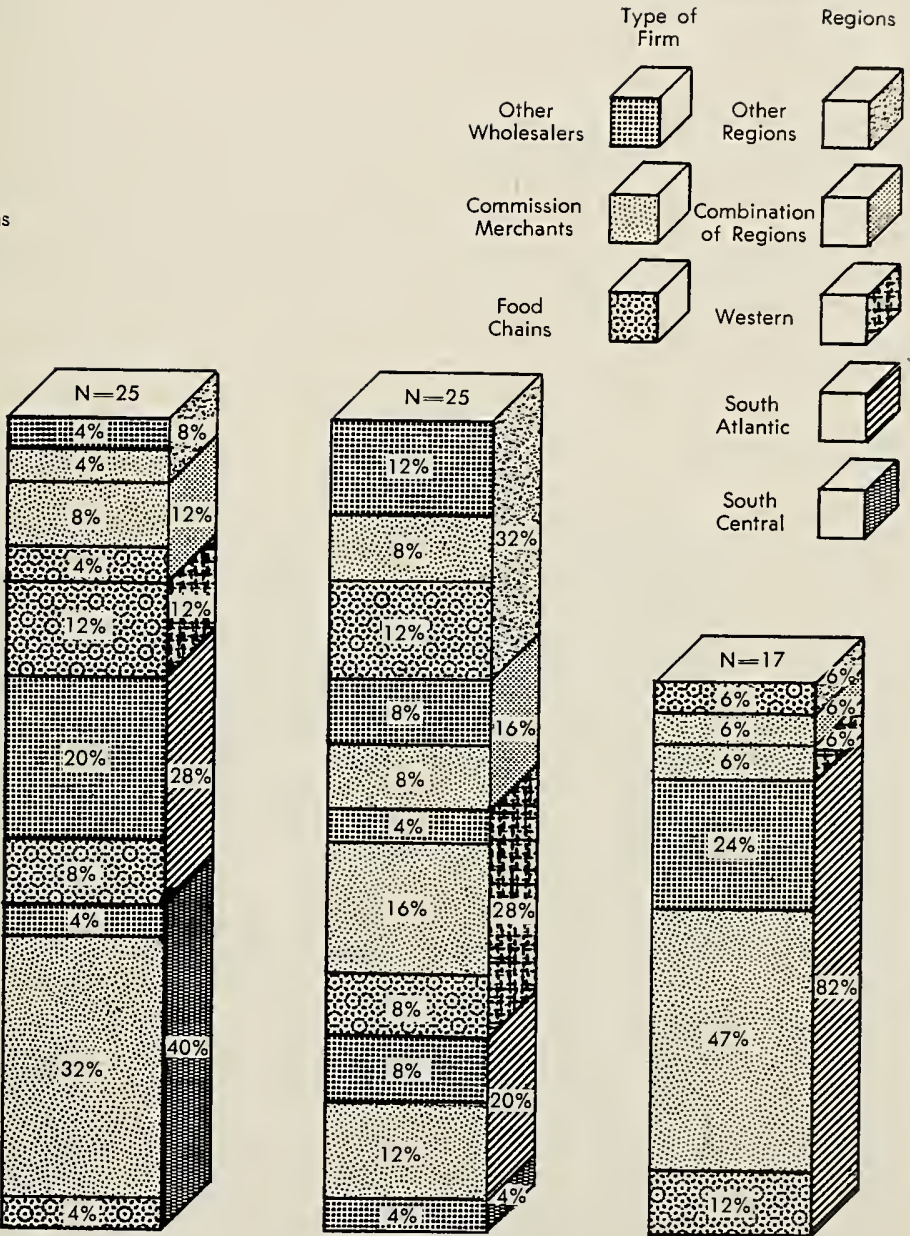

Southwestern

Market

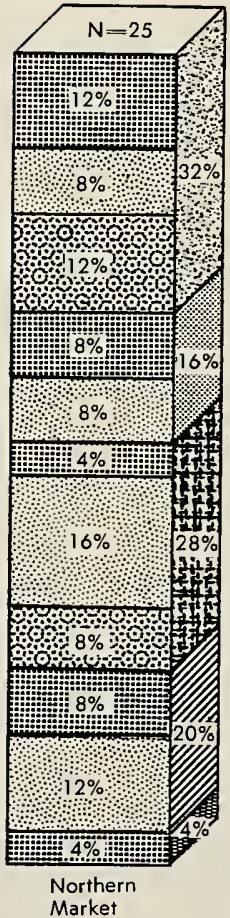

South

Atlantic

Central

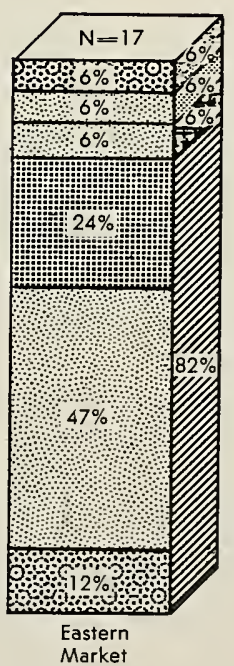

Figure 5. Primary regional source of strawberry supply (May 15-31) distributed by three market areas and three types of firms. 
Number of Firms

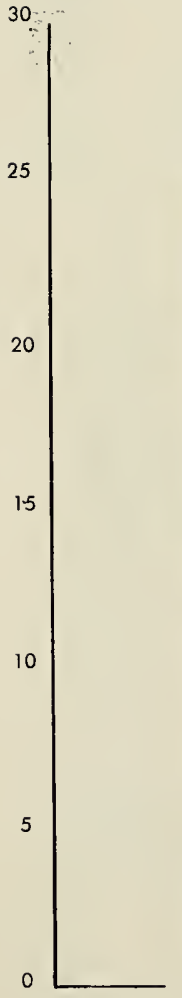

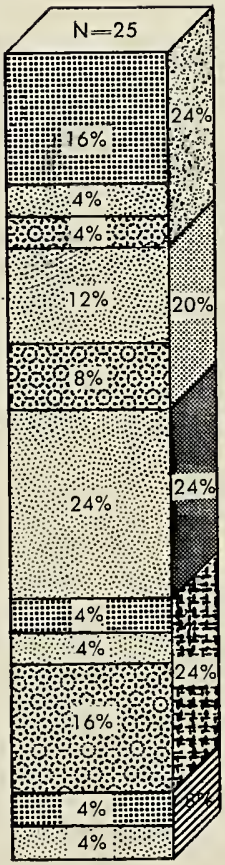

Southwestern Market

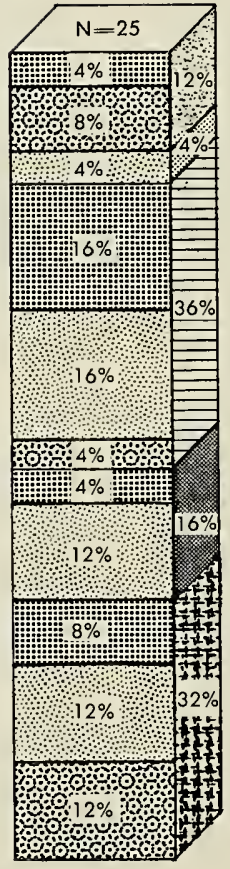

Northern Market
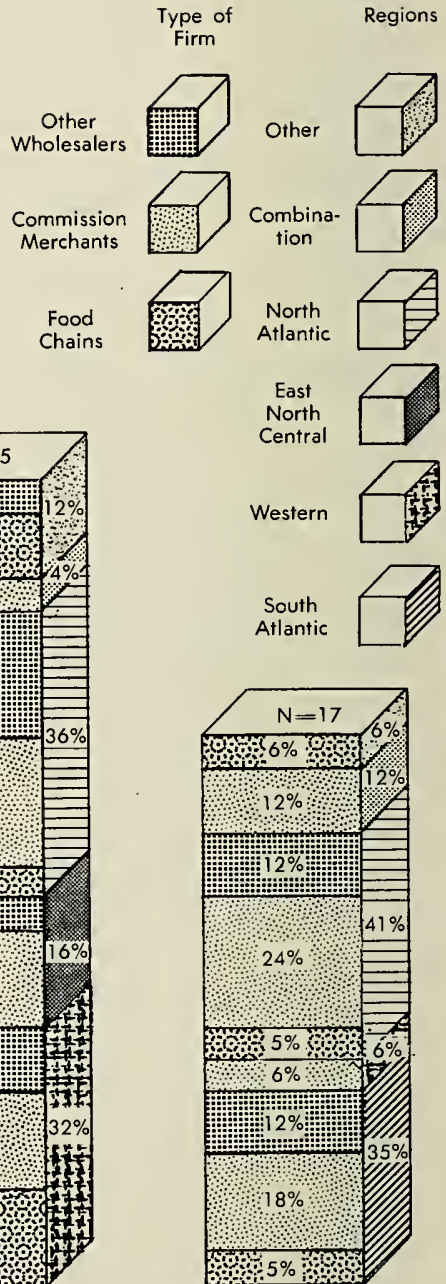

Eastern Market

Figure 6. Primary regional source of strawberry supply (June 1-15) distributed by three market areas and three types of firms. 
From June 16-30, the East North Central and Western regions are primary suppliers for 72 per cent of the buyers in the southwestern market (Figure 7). During the same time period, North Atlantic and Western regions are primary suppliers of strawberries for 56 per cent of the buyers in the northern market and for 71 per cent of the buyers in the eastern market.

Buyers shifting to different supply regions as the season progresses is what one would expect. The highly seasonal production of strawberries must shift with the seasons in the United States. Figures 5, 6, and 7 show that buying firms also shift their primary source of supply along with the season to obtain the volume and quality of strawberries desired for their customers. By having knowledge of the seasonal shift of primary supply regions for particular markets, strawberry producers can determine the market in which their strawberries can be most competitive during the different seasonal time periods.

Data in Figure 8 show the percentage of buyers in each market that indicated various regions as primary sources of strawberries during the three time periods. During the early part of the strawberry season (May 15-31) West Virginia strawberries may be more competitive in the northern than in the southwestern or eastern markets. From May 15 to May 31 a large proportion ( 48 per cent) of the buyers in the northern market are supplied primarily with strawberries produced in the Western and South Atlantic regions. Strawberries produced in these two regions must be shipped relatively long distances to the northern market. Furthermore, strawberries from the South Atlantic states probably pass through West Virginia on their way to the northern market. If one can use shipping distance as a factor in competition, strawberries produced in West Virginia during the May 15-31 time period should be competitive with fruit from the Western and South Atlantic regions being sold in the northern market.

Although the North Atlantic states are the major source of strawberry supply for the northern market during June 1-15, the Western states have increased in importance as suppliers. During May 15-31 Western states were mentioned as major sources of supply by 28 per cent of the buyers interviewed. However, during June 1-15 the Western states were mentioned by 32 per cent of its buyers. Again these Western berries are shipped long distances, and it would appear that West Virginia berries could be competitive with Western berries in the northern market during marketing period June 1-15.

During June 16-20 West Virginia sellers probably could be more competitive in the Southwestern market where 76 per cent of the buyers said their major source of supply was from the Western and East North 
Number of Firms

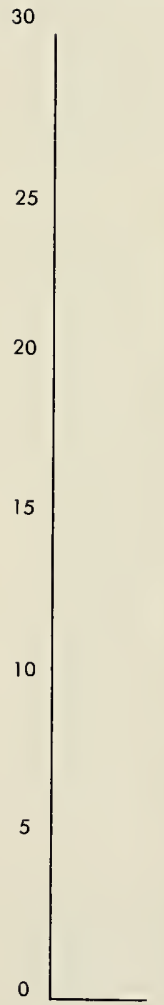

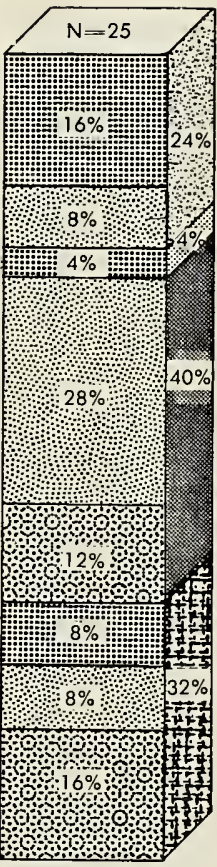

Southwestern Market

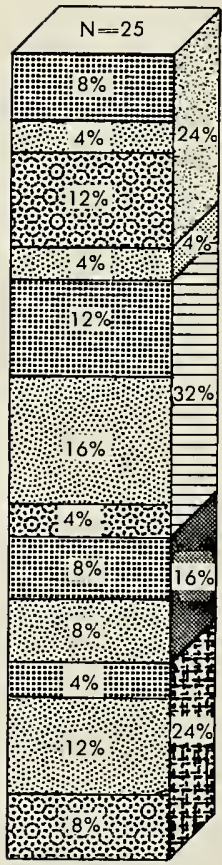

Northern

Market
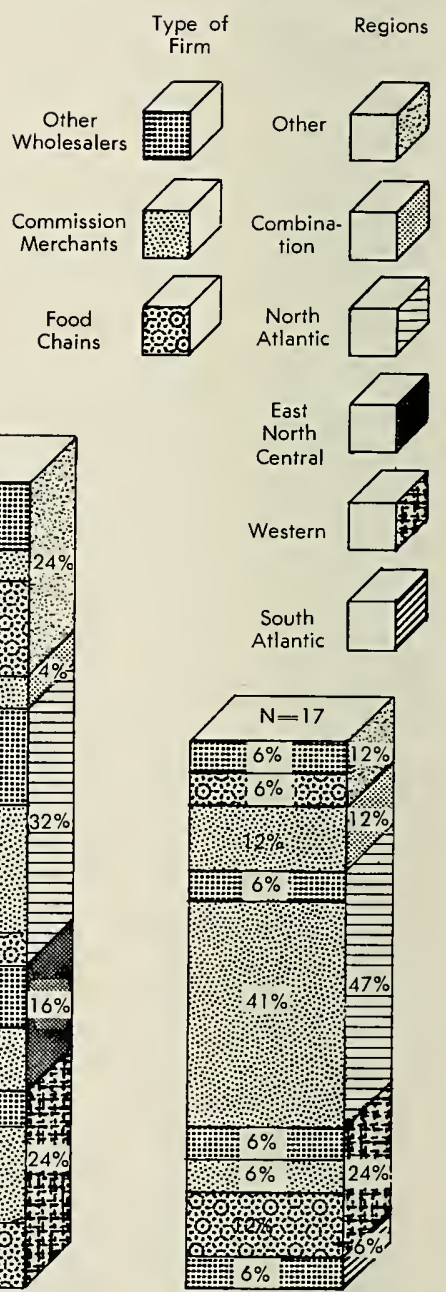

Eastern

Market

Figure 7. Primary regional source of strawberries (June 16-30) distributed by three market areas and three types of firms. 


\section{Primary Regional Source of \\ Strawberries}

South Central

South
Atlantic

Western

East North Central

North Atlantic

Combinations of Regions

Other Regions
South

Western

Market

(Percent)

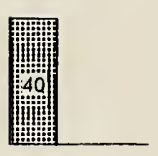

4

卌曲
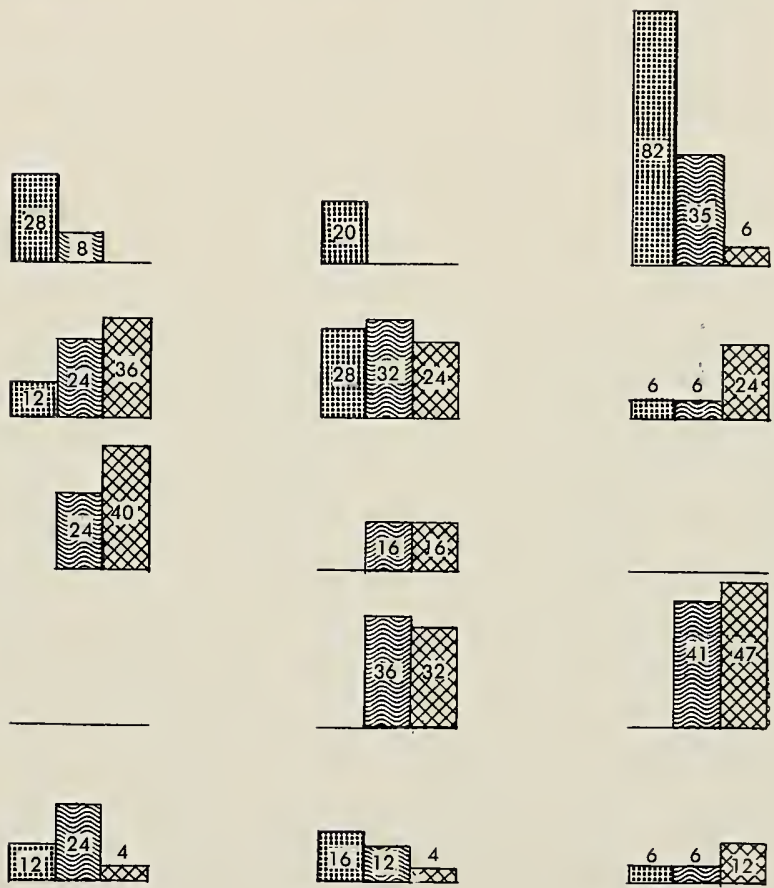

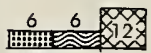

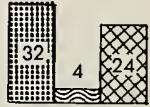

京 喜

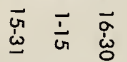

Estern

(Percent)

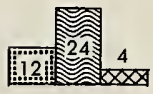

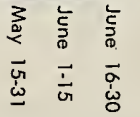

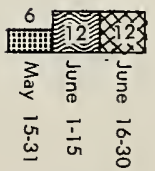

Figure 8. Primary regional source of strawberries distributed by three market areas and three time periods. 
Central states. West Virginia berries probably could compete favorably with berries from the Western states in this market.

\section{DAILY VOLUME}

In order for producers to coordinate their picking and shipping activities with buyers' demand, producers need to know which days the buying firms are closed and which days the volume moved toward consumers by the buyers is light, moderate, or heavy. To obtain this information the buyers were asked how their weekly volume would be distributed among the days of the week if the retail price of strawberries was 45 to 49 cents a quart.

The majority of buyers in the southwestern market reported that the volume moved toward consumers on Monday and Tuesday was light to moderate (Figure 9). On Wednesday the volume was light to heavy. Thursday and Friday were reported by a majority of buyers as being heavy volume days. Most buyers indicated they were closed on Saturday. On Sunday most firms were closed or only handled a light volume. Although one would expect a difference in heavy, moderate, and light volumes for wholesale and retail firms, there does not appear to be a significant difference in the way weekly volume is distributed to consumers by different types of buying firms.

A comparison of the weekly volume distributed by day of week and type of buying firm in the northern market (Figure 10) and eastern market (Figure 11) to the southwestern market (Figure 9) shows a similar pattern for all three markets.

The relative daily volume shown in Figures 9, 10, and 11 probably is a function of the buyers' market for strawberries. That is, most stores retailing strawberries probably want to prepare for heavy customer buying for week-end consumption; thus, Thursday and Friday would be big buying days for consumers.

The information shown in Figures 9, 10, and 11 also suggests that producers could coordinate their marketing activities in such a way that they could sell in either market or to either type of buying firm with the same marketing program. In order to minimize the time lapses between harvest and consumption, buyers probably prefer that strawberries arrive at their firms sometime between midnight and 6 a.m. on the heavy volume day (Figure 13).

\section{SIZE AND QUALITY DESIRED}

Buyers in the three markets were asked which one of the following two size-quality options they would prefer to handle:

Option \#1-U.S. No. 1 or combination containing fruits of vari- 
LEGEND
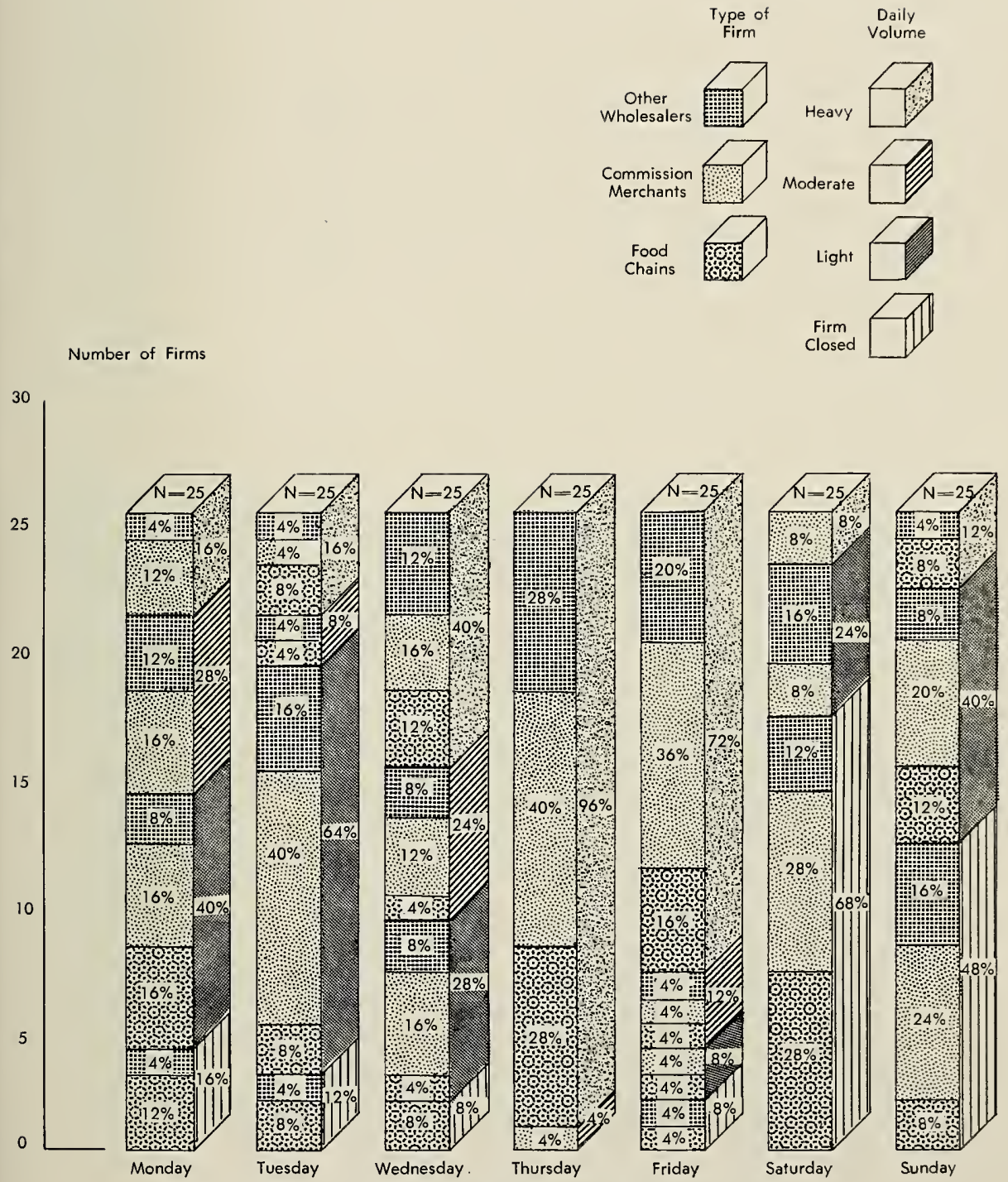

Figure 9. Weekly volume of strawberries handled when retail price is $45 \mathrm{c}$ to $49 \mathrm{c}$ a quart distributed by days and three types of firms in the Southwestern market area. 
Number of Firms

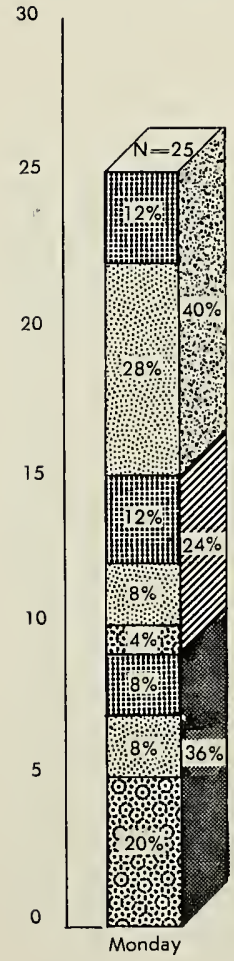

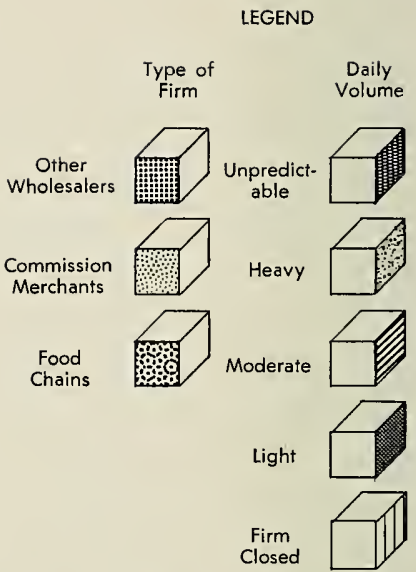

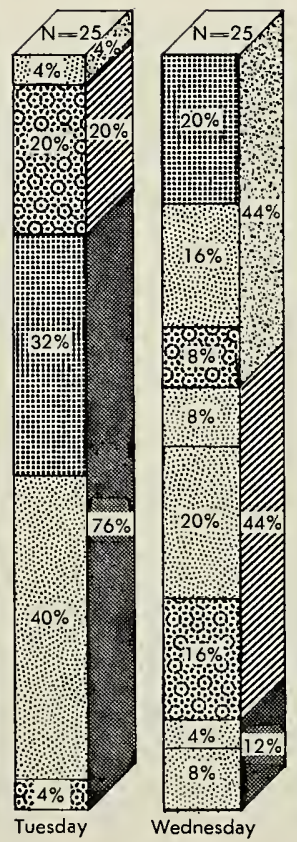

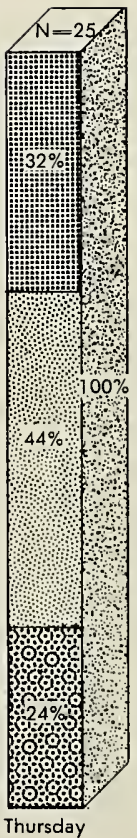

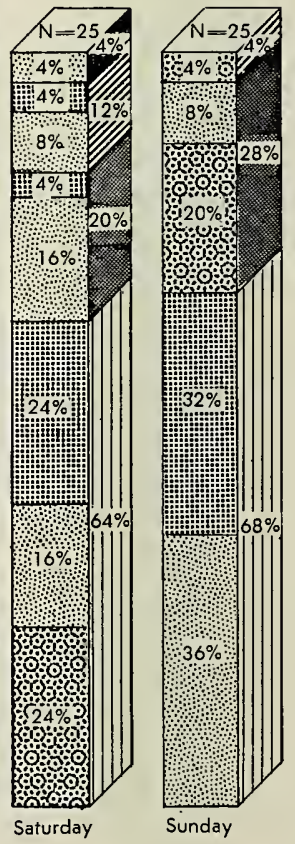

Figure 10. Daily volume of strawberries handled when retail price is $45 \mathrm{c}$ to $49 \mathrm{c}$ a quart distributed by days and three types of firms in the Northern market area. 
LEGEND

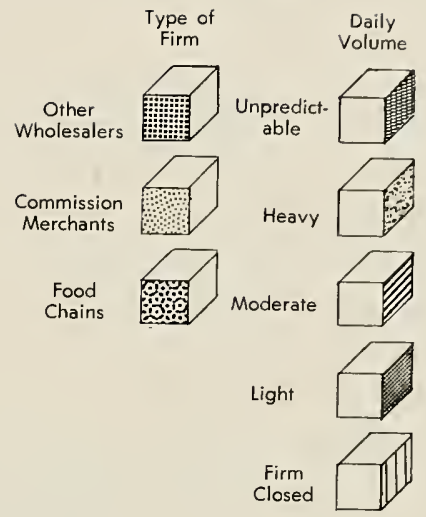

Number of Firms

20

10

0

L

Monday
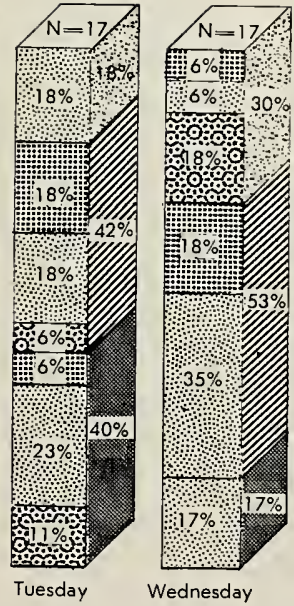
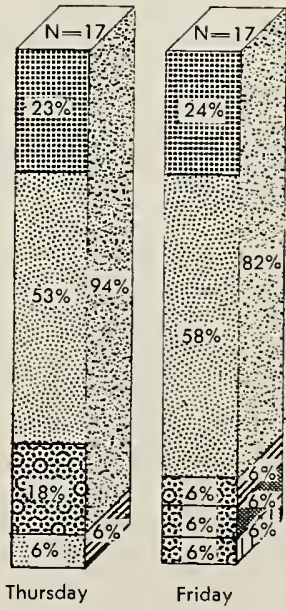

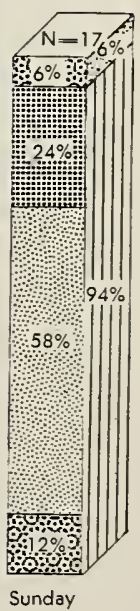

Figure 11. Daily volume of strawberries handled when retail price is $45 c$ to $49 c$ a quart distributed by days and three types of firms in the Eastern market area. 
LEGEND

Number of Firms

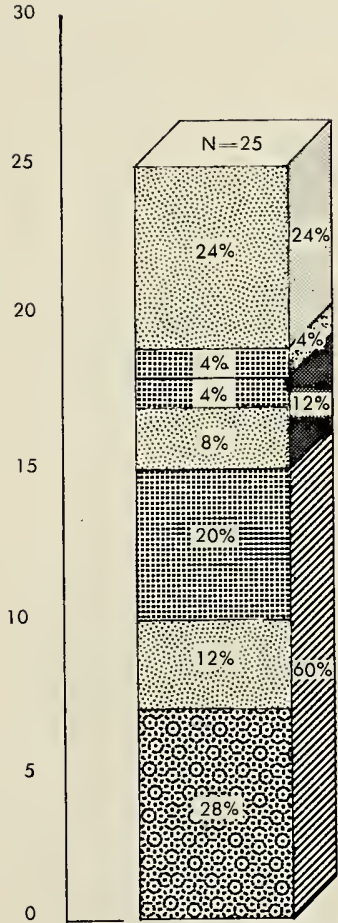

Southwestern

Market
Type of

Firm

Other Wholesalers

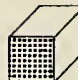

Commission Merchants

Food

Chains

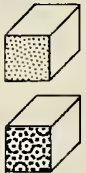

Equal amounts of Option \#1 \& Option \#2

Mostly Option \#1 and some Option \#2

Mostly Option \#2 and some Option \#1

Size and Quality Option*

Only Option \#2

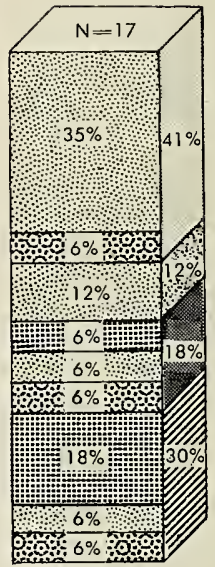

Northern

Market

Figure 12. Size \& quality option selected distributed by three market areas and three types of firms.

*Option \#1-U.S. No. 1 or combination containing fruits of various sizes but many small fruits which can be retailed at $39 \mathrm{c}$ or 3 for $\$ 1.00$

*Option \#2-U.S. No. 1 uniformily large and excellent quality which can be retailed for $45 c$ to $49 c$. 
LEGEND

Number of Firms

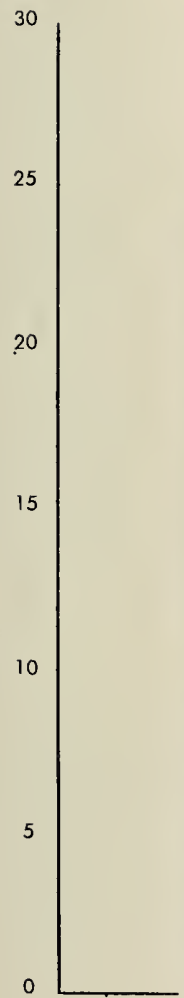

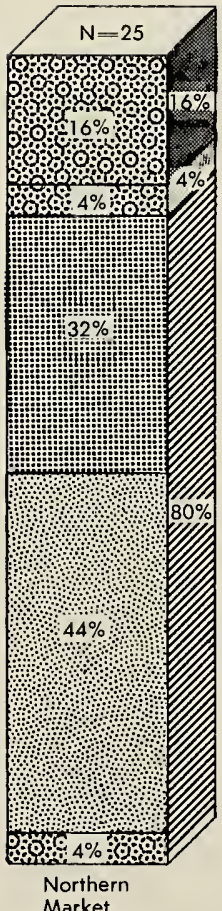

Delivery

Time

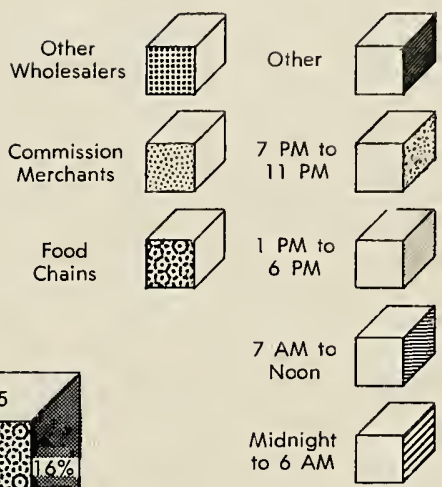

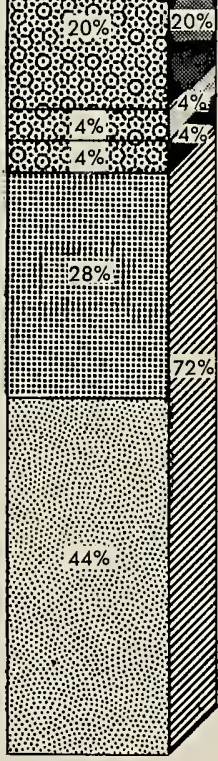

Southwestern Market

Market

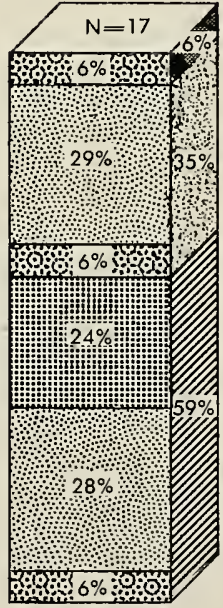

Eastern

Market

Figure 13. Desired time of strawberry delivery distributed by three market areas and three types of firms. 
ous sizes but many small fruits which can be retailed at 39 cents per quart or 3 quarts for one dollar.

\section{Option \#2-U. S. No. 1 uniformly large and excellent quality which can be retailed for 45 to 49 cents per quart.}

More than 55 per cent of the buyers in the southwestern and northern markets preferred to handle the uniform, large, quality strawberries offered in Option \#2 (Figure 12). Only 30 per cent of the buyers in the eastern market preferred Option \#2, and 41 per cent said they would prefer handling equal amounts of both options. It is interesting to note that no buyers in any of the three markets selected only Option \#1.

Food chains in the southwestern and northern markets were more inclined toward the large, high-quality strawberries than chains in the eastern market. In all three markets the majority of the commission merchants indicated that they preferred strawberries other than the uniform, large, excellent-quality berries (Option \#2). At least 50 per cent of other wholesalers in all three markets preferred to handle the highquality berries (Option \#2). A larger proportion of food chains and other wholesalers selected the best quality strawberries (Option \#2) than did commission merchants.

The difference between the large percentage of buyers in the southwestern and northern markets and the small percentage of buyers in the eastern market who preferred the high-quality strawberries may be explained partially by the high proportion of commission merchants that exist in the eastern market.

\section{DESIRED TIME OF DELIVERY}

The organizational structure of a buying firm influences the time of day that delivery of goods is desired. That is, firms employing only one shift of workers may want delivery of goods between 8 a.m. and 5 p.m. Firms having more than one shift of employees may want night delivery to facilitate storing, packaging, and displaying the product for the next day's business.

More than half of the buyers in all three markets wanted strawberries delivered between midnight and 6 a.m. (Figure 13).

All other wholesalers in the three markets and all commission merchants in the southwestern and northern markets wanted strawberries delivered between midnight and 6 a.m. Food chains seemed to prefer other hours for delivery such as 9 a.m. to 3 p.m. or 7 a.m. to 5 p.m. Thirty-five per cent of the buyers in the eastern market preferred that strawberries be delivered between 7 p.m. and 11 p.m. 

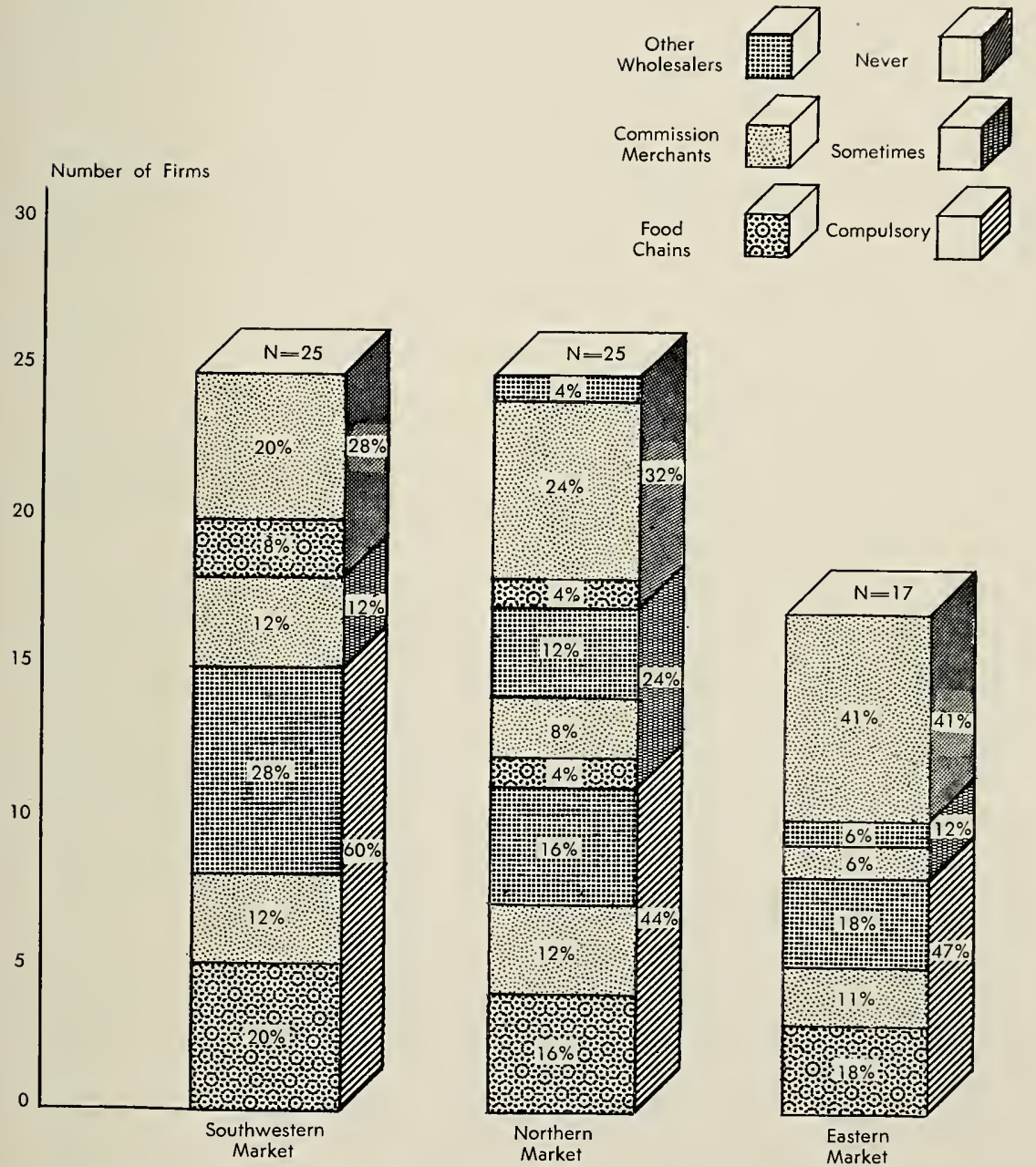

Figure 14. Refrigeration requirements for strawberry shipments distributed by three market areas and three types firms. 
Harvesting activities in West Virginia should be organized in such a way as to permit strawberries to arrive at the buyers' firms between midnight and 6 a.m. Possibly the berries could be picked in the morning and placed in coolers at assembly points to be loaded and shipped from these points by 6 p.m. This time schedule would permit the strawberries to arrive at the buying firms in all three markets between midnight and 6 a.m. This arrangement would permit most of the strawberries to be in the consumers' possession within 24 hours after harvest.

\section{SHIPPING UNDER REFRIGERATION}

More than 40 per cent of the buyers in all three markets indicated that it was compulsory that strawberries be shipped to them under refrigeration (Figure 14). Twelve per cent or more of buyers in all markets said refrigeration was needed sometimes. Twenty-eight per cent or more of the buyers in these markets indicated that strawberries should never be shipped under refrigeration.

In all markets the largest proportion of food chains and other wholesalers require that the strawberries be shipped under refrigeration, while the largest proportion of commission merchants in the three markets never wanted refrigerated shipments.

Different refrigeration requirements by the three types of buyers probably is the result of the various marketing functions performed by each buyer. Food chains normally have facilities to keep the berries under refrigeration until sold to consumers. Commission merchants normally do not maintain refrigeration facilities. Therefore, if strawberries were shipped under refrigeration and not kept under refrigeration by the buyer, quality would deteriorate more rapidly than if they had not been shipped under refrigeration. Other wholesalers probably have facilities to keep berries cool after receipt until they can be marketed.

\section{TYPE OF PACKAGE PREFERRED}

Quart containers were preferred for strawberries by more than 45 per cent of the buyers in all three markets (Figure 15). Pint containers were the second most popular in all markets.

Except in the northern market, more food chains preferred pint than quart containers. In all markets, commission merchants strongly preferred quart over pint containers. Container preference by other wholesalers varied with the market considered. 
Number of Firms

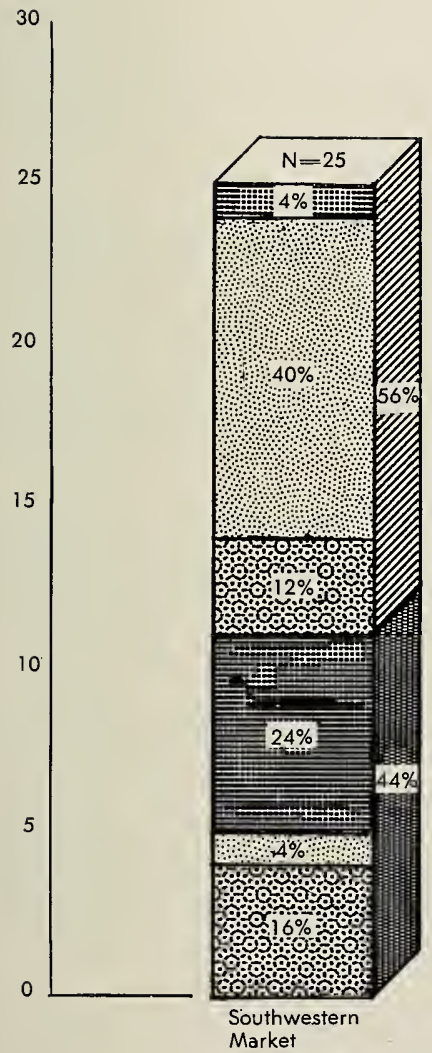

LEGEND

$\begin{array}{cc}\text { Type of } & \text { Desired } \\ \text { Firm } & \text { Package }\end{array}$

Other

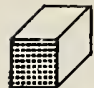

Combinațions

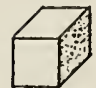

Commission

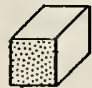

Quarts

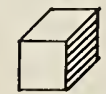

Food

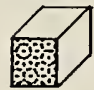

Pints

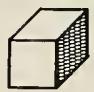

Figure 15. Type of package preferred for strawberries distributed by three market areas and three types of firms. 


\section{SUMMARY STATEMENTS}

1. Buyers in the northern markets were more favorable toward handling West Virginia strawberries than were buyers in southwestern and eastern markets.

2. Commission merchants and food chains were more favorable toward handling West Virginia strawberries than were other wholesalers.

3. Selling by consignment was mentioned most frequently by buyers in all three markets as the preferred method of selling (first choice) that West Virginia strawberry producers should use.

4. Commission merchants favored consignment; food chains favored direct purchase, and buying agency; and other wholesalers favored direct purchase as the first choice selling method that should be used by West Virginia strawberry producers.

5. In all three markets, about 50 per cent of the buyers did not state a preferred second choice selling method that should be used by West Virginia strawberry producers.

6. The region which was the primary supplier of strawberries from May 15 to 31, June 1 to 15 and June 16 to 30 varied with the location of the market.

7. Thursday and Friday were heavy volume days in all three markets. Most buying firms were closed on Saturday and Sunday. The pattern of daily volume appeared to be similar for all three types of buying firms.

8. Food chains and other wholesalers indicated a greater interest in high-quality strawberries than did commission merchants.

9. Most commission merchants and other wholesalers wanted strawberries delivered between midnight and 6 a.m. Food chains wanted strawberries delivered other hours such as 9 a.m. to 3 p.m. or 7 a.m. to 5 p.m.

10. Most food chains and other wholesalers indicated it was compulsory to refrigerate strawberry shipments. A large proportion of commission merchants said strawberries should never be shipped under refrigeration.

11. Food chains seemed to favor strawberries packaged in pint containers, while commission merchants and other wholesalers preferred quart containers. 


\section{CONCLUSIONS}

Analysis of data in this study suggest that markets are available for strawberries produced in West Virginia. However, strawberry producers must make every effort to package, grade, refrigerate, and transport their strawberries according to the desires of the particular buyer-food chains, commission merchants and other wholesalers. West Virginia strawberries should be sold in the market in which they can be most competitive. This may mean shifting to different markets during the harvesting season. 
